\title{
Using intentional humour in a higher education classroom: connecting with, and building on Lovorn and Holaway (2015)
}

\author{
Jannie Pretorius \\ University of the Free State, South Africa \\ pretoriusjph@ufs.ac.za
}

\section{Mariëtte Koen}

Northwest University, South Africa

Mariette.Koen@nwu.ac.za

\section{Robert Schall}

University of the Free State, South Africa

schallR@ufs.ac.za

\begin{abstract}
Positive humour can facilitate learning. From an educational perspective, it is important to examine how, when and why humour elicits a positive feeling in students, which, in its turn, creates an environment conducive to learning. Previous studies in humour research have focused on the generally perceived impact of humour in educational settings. Reflection on this idea gives rise to two questions. Will the use of intentional humour as a pedagogical tool indeed be perceived as such by students? Also, will a lecture containing positive humour affirm the impact of humour reported in academic literature? The researchers therefore decided that a lecture containing intentional humoristic elements would be presented to two groups of students with a view to determining their responses. To accomplish this, a mixed-methods approach was used, one employing a concurrent embedded nested design to explore the role and impact of intentional humour in two higher-education classrooms. A Likert-scale survey exploring six themes was developed regarding the impact of humour, as identified by Lovorn and Holaway (2015). Open spaces were provided to allow participants to expand quantitative responses. While the Mantel-Haenszel chi-square test statistic was used to analyse the quantitative data, content analysis was used to analyse the qualitative data. The theoretical framework for this paper was drawn from the instructional humour process theory (IHPT). Trustworthiness was gauged by applying Lincoln and Guba's (1985) model of trustworthiness. The findings of the paper are in line with Lovorn and Holaway's (2015) research, which suggests that when lecturers take advantage of the positive attributes of humour, it has the power to fuel both students' engagement and their learning.
\end{abstract}


Keywords: intentional humour, Lovorn and Holaway (2015), higher education classroom, learning, teaching humour

\section{Introduction}

While many researchers consider the ability to be humorous as an indispensable trait of a teacher, the higher education classroom is traditionally not associated with laughter (Bakar 2018: 1; Offer et al. 2018: 135; Morreall 2014: 120). Instead, the teaching and learning environment of pre-service teachers is usually perceived to be a serious domain built on discipline and where critical inquiry, reasoning and curiosity are facilitated. We, however, believe that there is no reason why lecturers cannot use humour to fuel curiosity and facilitate learning, even in this educational context. Curiosity can simultaneously create a motivation to learn and intellectual freedom, which in turn can prompt students to become actively involved in learning activities (Kaufman 2017: 1-3).

Despite some claims that there is no place for laughter in the higher education context, much has been published about the perceived benefits of using humour in lecture halls (Alkhattab 2012: 5; Huss \& Eastep 2016: 43). Berk (2002: 1) points out that humour is vital for the two most essential ingredients in education, namely the lecturer-student relationship and engaged learning. If used appropriately, humour can be linked to a positive outcome such as improved retention of complex subject matter (Lovorn \& Holaway 2015: 25; Offer et al. 2018: 135). According to Davenport (2015: 5), humour is a major psychological tool that enhances intellectual health by lessening tension and stress in the classroom. Lei et al. (2010: 326-329) add that laughter is a stimulant, which leads to physical, psychological, social and cognitive benefits. A humorous lecture can potentially increase the release of endorphins and also reduce muscle tension and anxiety (Alkhattab 2012: 5). This process serves a psychological purpose by enhancing students' sense of well-being, their self-image and their self-confidence, while encouraging risk-taking (Davenport 2015: 5; Lei et al. 2010: 326-329; Wortley 2016: 13). Possible cognitive benefits include making boring subjects and difficult courses more memorable, increasing students' attention and motivation, developing problem solving, capturing and maintaining students' attention, and developing good retention (Jeder 2015: 828829; Lei et al. 2010: 326-329). Humour seems to prompt students to investigate, ask critical questions, learn from mistakes and enhance confidence to solve problems (Chabeli 2008: 16). Humour can also serve a social purpose by creating a relaxed atmosphere for learning and a positive learning climate, building rapport between lecturer and students, enhancing social cohesion and encouraging a sense of trust (Lei et al. 2010: 326-329; Malamed 2018: 1).

Notwithstanding the above documented benefits, humour is often not considered a pedagogical tool (Offer et al. 2018: 135; Morrison 2008: 73; Azizinezhad \& Hashemi 2011: 2094). It seems as if lecturers do not take advantage of or acknowledge the positive attributes of humour, perhaps because they fear laughter in their classrooms (Morreall 2014: 120). While using humour surely does not mean that lecturers should entertain students by acting like comedians (Vu \& Vu 2012: 44), it would appear that they are either reluctant or uncomfortable to use humour in their lectures (Morrison 2008: 73). Other reasons why lecturers choose not to use humour in their classrooms may include negative consequences, such as when humour causes a distraction or a disruption (Freitas 2018: 12; Strong 2013: 31). If offensive and inappropriate humour is used, it can compromise the integrity of the academic endeavour (Azizinezhad \& Hashemi 2011: 2094).

When students are asked to describe good lecturers, humour is a quality to which they refer (Lei et al. 2010: 326). It is believed that the days of the "Ivory Tower", when lecturers aimed to transmit knowledge in sixty-minute lectures, are over (Wortley 2016: 14). In fact, many years 
ago, Baughman (1979: 28) already remarked that "one of the greatest sins in teaching is to be boring."

\section{Motivation for this study}

Teaching effectiveness is an ongoing challenge in higher education environments. Lovorn and Holaway (2015: 26) hold that humour offers an opportunity to create a positive learning environment that is conducive to learning. Although the influence of humour in the higher education classroom has been widely researched, few studies have focused on how lecturers specifically apply humour when they teach (Lovorn \& Holaway 2015: 26). The latter authors used online discussions to explore perceptions among teachers - from kindergarten to Grade 12 (K-12) - of the use of humour as a teaching, interaction and a management strategy in the classroom (Lovorn \& Holaway 2015: 24.). Although we are working in the field of tertiary education, we are training students to function in K-12 school environments. As such, we considered their discourses and results to be relevant for our students.

From these discourses, Lovorn and Holaway (2015: 26-8) were able to establish that the participating teachers $(n=31)$ had some understanding of how humour influenced teaching and learning, students' engagement and motivation, and how it affected teachers' confidence in interaction with students. Their data also revealed the various challenges and possible resistance to the use of humour in the classroom. Their findings indicated that while most participating teachers could demonstrate examples of their use of humour in the classroom, few appeared to perceive humour as a structured classroom strategy. Additionally, their study revealed that while participating teachers were open to the idea of using humour in the classroom, most did not deliberately or strategically include it in the planning or implementation of their lessons (Lovorn \& Holaway 2015: 24).

We were unable to find a study in which an intentionally humorous lecture was "administered" to participating students prior to their responses to such a specific "intervention." Gonulal (2018), for example, conducted an attitudinal investigation into the potential of humour in English First Language classrooms in Turkey, based on the collective previous general experiences of the use of humour in the classes that the 250 participants in their study had attended. While Gonulal's study is a very useful one, no specific, intentionally humorous lecture was included in his methodology. The first aim of our research, then, is to fill this gap by deliberately planning and presenting a humorous lecture and quantitatively and qualitatively determining the impact on students or their responses.

In addressing the use of humour in classrooms from the responses in their study, Lovorn and Holaway (2015: 28) identified six themes (see Table 1): classroom effectiveness: management (CEM); classroom effectiveness: teaching (CET); classroom effectiveness: interaction (CEI); teacher preparation (TP); positive factors that influence teachers' decisions to use humour in the classroom (PF); and, finally negative factors that influence teachers' decisions to use humour in the classroom (NF).

To us, their descriptions of these themes seemed very convincing and useful - to the extent that we wanted to share the essence of the findings with our students while investigating the usefulness of these ideas within our own context. The second aim of our study, then, was to establish the perceived appropriateness or usefulness of some of the content of their research. We hoped that this would contribute towards the process of establishing a useful, sound and valid body of knowledge within the field of humour research.

Based on the above, we formulated the following two research questions: 
Table 1. Themes and sample content summarised from Lovorn and Holaway (2015: 27-31)

\begin{tabular}{|c|c|}
\hline $\begin{array}{l}\text { Themes from Lovorn } \\
\text { and Holaway (2015: 27- } \\
\text { 31) }\end{array}$ & Sample content under each theme \\
\hline $\begin{array}{l}\text { Classroom effectiveness: } \\
\text { management (CEM) }\end{array}$ & $\begin{array}{l}\text { - Can be an effective classroom management tool (if used } \\
\text { properly) } \\
\text { - Captures learners' attention and encourages them to be in } \\
\text { class } \\
\text { - Creates an environment that reduces stress } \\
\text { - Learners feel happy, comfortable and open }\end{array}$ \\
\hline $\begin{array}{l}\text { Classroom effectiveness: } \\
\text { teaching (CET) }\end{array}$ & $\begin{array}{l}\text { - Impact overwhelmingly positive } \\
\text { - Increases learner engagement and participation } \\
\text { - Facilitates learners' willingness to take risks }\end{array}$ \\
\hline $\begin{array}{l}\text { Classroom effectiveness: } \\
\text { interaction (CEI) }\end{array}$ & $\begin{array}{l}\text { - Can both positively and negatively impact classroom } \\
\text { interactions } \\
\text { - Helps teacher to know learners better } \\
\text { - Helps learners to be more comfortable with both their teacher } \\
\text { and other learners } \\
\text { - Helps learners with different cultural backgrounds to } \\
\text { connect: develops patience, respect and openness }\end{array}$ \\
\hline $\begin{array}{l}\text { Teacher preparation } \\
\text { (TP) }\end{array}$ & $\begin{array}{l}\text { - No formal training required } \\
\text { - Observed other teachers (when they were learners) } \\
\text { - Emulate other teachers in one's own classroom } \\
\text { - Hesitant because of lack of training }\end{array}$ \\
\hline $\begin{array}{l}\text { Positive factors that } \\
\text { influence teachers' } \\
\text { decisions to use humour } \\
\text { in the classroom (PF) }\end{array}$ & $\begin{array}{l}\text { - Improves learners' attention, motivation and learning } \\
\text { - Can also make the classroom a more comfortable and } \\
\text { engaging learning environment for learners } \\
\text { - Encourages their academic and behavioural success } \\
\text { - Leads to higher order thinking } \\
\text { - Increases creativity } \\
\text { - Leads to deep knowledge relating to subject matter }\end{array}$ \\
\hline $\begin{array}{l}\text { Negative factors that } \\
\text { influence teachers' } \\
\text { decisions to use humour } \\
\text { in the classroom (NF) }\end{array}$ & $\begin{array}{l}\text { - Teachers fear losing control of learners. } \\
\text { - There may be resistance to the use of humour in the } \\
\text { classroom. } \\
\text { - There could be pressure from school administrators. } \\
\text { - Societal complexities }\end{array}$ \\
\hline
\end{tabular}

1. Would an intentional, planned humorous lecture be perceived as such by student respondents?

2. Would the six themes regarding the perceptions of teachers about the use of humour in classrooms, as identified and discussed by Lovorn and Holaway (2015: 27-31), also be perceived to be useful and applicable in a classroom environment by the student respondents?

At this stage, we have to emphasise that, although these aims and questions were distinct, they were by no means intended to be separated: we were acutely aware that the success or failure of the humorous lecture would have a profound effect on the perceptions of the students as to the applicability of the themes presented by Lovorn and Holaway (2015). We assumed that 
our effort would be backdropped by a causal relationship between the lecturer, the six themes and the students' responses.

\section{Background, definition and theoretical framework}

All human beings are predisposed to laughing (Alatalo \& Poutiainen 2016: 66; Malamed 2018: 1). Even babies as young as three months can laugh, especially if they feel comfortable in a safe environment (Alkhattab 2012: 1). Humour is not the same as laughter and involves a more complex construct, in the sense that it cannot exist in a vacuum (Alatalo \& Poutiainen 2016: 66; Strong 2013: 2). It needs an audience or, as Strong (2013: 32) suggests, "an other". Over the years, lecturers experimented with this "other" in their classrooms whenever they wove humour into their lectures with the aim of creating an environment conducive to learning (Seidman \& Brown 2016: 43).

Humour is not a new concept. While humour can be seen as a universal phenomenon, the concept is not "homogenous" (Banas et al. 2011: 117). The interpretation of the concept of humour is subjective. Different people perceive different things as comical or amusing (Ocon 2015: 3). Some researchers believe that people are amused when they feel relieved (Healy, 2018). Relief theorists view laughter as a way to relieve psychological energy in finding forbidden things hilarious (Morreal, 2016).

Humour scholarship owes credit to ancient philosophers like Plato, Aristotle, Cicero and Quintilian (Perks 2012: 119), who held that humour adds value to social relationships (Mayo 2010: 511). It appears that the first teacher to have used humour in the introductions to his lectures was a Talmudic teacher, Rabbah, who lived in ancient Babylon about 1,700 years ago (Alkhattab 2012: 5). Rabbah believed that humour would create an environment conducive to learning when a pleasant response was elicited from students (Alkhattab 2012: 5).

There are numerous ways to define or interpret humour, since there is no universally valid definition (Offer et al. 2018: 135). Lovorn and Holaway (2015: 25) clarify humour as the ability to arouse comic responses or make people laugh. Booth-Butterfield and Booth-Butterfield (1991: 206) elaborate on this idea by asserting that "humour is an intentional verbal [or] nonverbal message which elicits laughter, chuckling, and other forms of spontaneous behavior taken to mean pleasure, delight and/or surprise in the targeted receiver". Additionally, Gervais and Wilson (2005: 399) summarise the idea of humour as "non-serious social incongruity". Loomans and Kolberg (1993: 14) claim that there are two opposing sides to humour when using it in the classroom. Lecturers can use it appropriately as a "social lubricant" or inappropriately as a "social retardant". Whether attention is sustained will depend on students' interpretation of the intended humour (Deiter 2000: 22). Taking all the above interpretations into consideration, humour, in this paper, is used to refer to both verbal and non-verbal communication that elicits positive feelings in the classroom while the lecturer interacts with the students.

We next turn to an exploration and interpretation of the relationship between the use of humour and student learning by reflecting on the fundamental principles of the instructional humour process theory (IHPT). According to Wanzer et al. (2010: 1-18), learning will take place when humour creates positive feelings, which will lead to better attention and enhanced motivation on the part of students as they attempt to understand and participate in the learning process. More specifically, IHPT seeks to explore why some forms of instructional humour are positively associated with student learning, while other types do not have an influence on learning (Freitas 2018: 16; Wanzer et al. 2010: 3). Two important considerations are relevant when using the principles of IHTP. First, the theory highlights the relevance of humour to course content, in which case it may increase motivation and the ability to decode the messages. In the 
second place, attention is paid to the appropriateness of humour to determine the affective response (Banas et al. 2011: 119).

IHPT draws on three theories, namely incongruity-resolution theory, disposition theory and the elaboration likelihood model (ELM) of persuasion (Banas et al. 2011: 119).

\subsection{Incongruity-resolution theory}

Berlyne's (1960) incongruity-resolution theory depicts humour as a binary process in which the perceived incongruity or inconsistency must initially be noted and then accurately understood and resolved in order to appreciate the humorous message (Offer et al. 2018: 137). In this theory, it is assumed that students enter the classroom context with a predetermined set of expectations regarding appropriate or inappropriate behaviour (Savage et al. 2017: 344). The humour comprehension, and not the humour appreciation, is at the core of this theory (Machlev 2015: 10). The mere recognition of the humorous stimulus is not enough, it should also be resolved and understood (Savage et al. 2017: 344). If the inconsistency is difficult to understand, it is possible that the humour will not be recognised, and the students will not be able to make sense of the incongruity in the lecturer's message (Bolkan \& Goodboy 2015: 47).

\subsection{Disposition theory}

The second theory, the disposition theory, relates to the importance of the affective element in the message and explains how messages can affect students' feelings and attitudes (Wanzer et al. 2010: 4). According to this theory, people describe humour as appropriate and possibly funny or inappropriate based on whether they associate themselves with the targeted subject (Savage et al. 2017: 345). Machlev (2015: 10) explains that two perspectives relate to the classroom: if the humour makes sense to students (the incongruity is comprehended and resolved) and the target of the humour is liked or a part of the referent group (disposition theory). He contends that the student will deem attempts at humour as appropriate when these attempts are related to course materials and understood within the setting of the classroom. This theory aims to outline why students consider attempts at humour as either a personal or group attack. Humour that ridicules course content can be considered appropriate (Savage et al. 2017: 345).

\subsection{Elaboration-likelihood model}

The third theory in the background of the IHPT provides an argument for the benefits of humour and illuminates key components of the impact on instructional humour and learning (Savage et al. 2017: 345). The elaboration likelihood model (ELM) developed by Petty and Cacioppo (1986) employs a dual process model to explain how people are persuaded to remember messages (Budzynska \& Weger 2011: 1). Applying the ELM theory to the higher-education classroom context suggests that when students perceive the humorous messages as relevant, they experience increased motivation to process the material, which results in enhanced retention and understanding of the course content (Alatalo \& Poutiainen 2016: 71). Davenport (2015: 8) explains that messages will undergo the process of persuasion in two different ways, namely the central and the peripheral route. The central route to persuasion consists of thoughtful consideration of the arguments contained in messages by means of systematic and straight-to-the-point analysis (Budzynska \& Weger 2011: 1). Applying this idea to the classroom, students process the information presented critically in an attempt to determine their cognitive responses. The peripheral route is heuristic, which means the outcome of persuasion is the result of less thoughtful processes and the outcome is influenced by cues other than the content or the logical merits (Budzynska \& Weger 2011: 1). The ELM argues that changes in 
attitude that result from central route processing will be more persistent than attitude changes that result from exposure to peripheral cues (Savage et al. 2017: 345).

Huss and Eastep (2016: 42, 43) summarise the main ideas of IHPT by suggesting that laughter in the classroom is a means of acknowledging the incongruity between the conceptions that students hold in their minds and what happens to upset their expectations. Such internal incongruity can increase attention, assist with information processing on a deeper level and enhance recall in a positive manner (Offer et al. 2018: 137). Bolka et al. (2018: 157) add a new dimension to humour research when they distinguish between contiguous and integrated humour. The authors explain that whereas contiguous humour is not tied to the content of the educational message and can be related or unrelated to core content, integrated humour is embedded in instructional activities. They argue that although contiguous humour might be beneficial in respect of motivating students to engage with their educational environments, integrated humour may function as a source of student distraction.

\section{Methodology}

This research was guided by a concurrent embedded nested mixed-methods research design (Creswell \& Creswell 2018: 237). The rationale for choosing this design is the idea that a single quantitative data set will not be sufficient to explore the intentionally humorous lecture and the themes of Lovorn and Holaway (2015: 28-31). The qualitative data set could provide a supportive, secondary role in the study (Kroll \& Neri 2009: 44). In a concurrent embedded nested design, one form of data collection is nested within another (larger) data-collection procedure to analyse different questions or levels of units (Wium \& Louw 2018: 13). In this study, the quantitative component carried more weight and the concurrent qualitative datacollection method was performed to provide a more comprehensive view of the humour phenomenon.

\subsection{Sampling}

In line with the first aim and research question, namely, to determine whether an intentional, planned humorous lecture would be perceived as such by student respondents, the first author planned and then presented two lectures - one in 2018 and one in 2019 - with a variety of humorous elements to two groups of pre-service teachers. Purposive sampling was used to present the lecture to the two groups (Kroll \& Neri 2009: 35). The first group comprised 44 student teachers and the second group 64 student teachers. The humorous elements, all presented by means of a single, multimedia PowerPoint slideshow, included a humorous video clip of $\mathrm{Mr}$ Bean in a chemistry laboratory, a section from the Bambi movie and humorous discussions of some of the reproductive strategies of flowers and a number of animals.

\subsection{Likert scale and open spaces}

A Likert-scale survey was developed to address the relevance and applicability of the themes identified by Lovorn and Holaway (2015) - see Table 2.

The survey contained statements in respect of which participants had to select responses varying from "Strongly disagree" (1) to "Strongly agree" (5). The quantitative items were supported by blank spaces in which students could add qualitative responses to clarify their views on the use of humour in the higher education classroom. The addition of the qualitative component seemed most suitable because it is generally believed to expand and strengthen the investigation on the phenomenon of humour in the higher education classroom (Johnson \& Christensen 2017: 478). 
We shall now discuss the nature of the Likert-scale surveys that we utilised to determine the students' responses in 2018 and 2019 (see Table 2). To address the first research aim and question, namely whether an intentional, planned humorous lecture would be perceived as such by student respondents, we included four items. We shall only mention one example: "Dr Pretorius should not try to be humorous." We did this to establish whether the students found the presentation and the content of the section about the reproductive strategies of animals humorous. We had hoped that it would provide a "fresh" or authentically humorous platform for the responses to the content selected from Lovorn and Holaway (2015: 27-31).

The rest of the items (e.g. "I have a deeper understanding of the reproductive strategies of organisms because of the humour.") had been developed and included to address the second research aim and question, which, as has been previously mentioned, aimed to address the relevance and applicability of the themes identified and discussed by Lovorn and Holaway (2015: 27-31). A critical reader of this article recommended that we explain the item "Showing the video clip of Mr Bean in the chemistry lab to learners is dangerous." We used the word "dangerous" since there is an explosion at the end of the video that might have caused considerable harm or even death to the learner in the video. The use of a humorous video clip that made fun of such an explosion might undermine safety in a laboratory.

Each of the items had been provided with some space for students to explain their responses. This added the qualitative dimension of our research. In the 2018 instrument, we had 19 items and in the 2019 instrument, we added three additional items. Since we want to compare the responses of 2018 with those in 2019, we shall focus only on the items included in both surveys in this article. We might analyse and present the additional items of the 2019 survey in a future article. The 2018 and 2019 surveys were subsequently processed and the responses analysed statistically and qualitatively.

Initially, the average score for the theme was calculated for each year (2018 and 2019), theme and participant. All of the further analyses were then based on these average scores (per year, theme and participant) by following a set procedure. For each year and theme, descriptive statistics (mean, standard deviation, minimum, median, maximum) were calculated. In order to assess any differences in survey results for the two years, the mean scores for each of the themes for the two survey years (2018 and 2019) were compared using the Mantel-Haenszel chi-square test (row mean-score test); the value of the chi-square statistics (1 degree of freedom in each case) and the associated P-values were reported (SAS, 2017). The Mantel-Haenszel chi-square test was chosen because it is a non-parametric test that does not require that the data (here: average scores per year and theme for each participant) follow a normal distribution.

Triangulation of the knowledge produced by the data allowed the researchers to test and further explore discrepancies while investigating the phenomenon of humour in a higher education classroom (Flick 2009: 444). Credibility was enhanced by repeating the 2018 research process in 2019.

Whereas the humorous topic of the first lecture in 2018 had been the reproductive strategies of flowers, the items in the 2019 survey were adapted to reflect the topic of animal reproduction. The purpose of repeating the research was to increase the validity of the results. It furthermore enabled us to perform a statistical comparison of the results. Dependability was enhanced by critically reflecting on the data and ensuring that data could be traced throughout the process. Confirmability was enhanced by being objective and staying neutral throughout the research process. 
Table 2. A summary of the themes and connected Likert scale items that had been included in the surveys of 2018 and 2019

\begin{tabular}{|c|c|}
\hline hemes & Likert scale items included in the surveys \\
\hline $\begin{array}{l}\text { PRET (the perceived } \\
\text { humorous nature of the } \\
\text { presenter and the } \\
\text { presentation) }\end{array}$ & $\begin{array}{l}\text { - The section about the reproductive strategies of organisms } \\
\text { was humorous. } \\
\text { - Dr Pretorius should not try to be humorous. } \\
\text { - I laughed at the jokes Dr Pretorius made. } \\
\text { - The videoclip of } \mathrm{Mr} \text { Bean in the chemistry lab was } \\
\text { humorous. }\end{array}$ \\
\hline $\begin{array}{l}\text { Classroom } \\
\text { effectiveness: } \\
\text { management (CEM) }\end{array}$ & $\begin{array}{l}\text { - Humour can help me to manage learners' behaviour. } \\
\text { - Humour does indeed create an environment that reduces } \\
\text { stress. }\end{array}$ \\
\hline $\begin{array}{l}\text { Classroom } \\
\text { effectiveness: teaching } \\
\text { (CET) }\end{array}$ & $\begin{array}{l}\text { - The video clip of Mr Bean in the chemistry lab is a valuable } \\
\text { teaching aid. } \\
\text { - I shall use humorous video clips as teaching aids. } \\
\text { - I am now confident that I should be able to explain the } \\
\text { reproductive strategies of organisms to learners. } \\
\text { - The presentation about the reproductive strategies of } \\
\text { organisms helped me to understand these strategies. }\end{array}$ \\
\hline $\begin{array}{l}\text { Classroom } \\
\text { effectiveness: } \\
\text { interaction (CEI) }\end{array}$ & $\begin{array}{l}\text { - Humour does indeed create a welcoming teaching and } \\
\text { learning environment. } \\
\text { - Humour does indeed help students from different cultural } \\
\text { backgrounds to connect. }\end{array}$ \\
\hline $\begin{array}{l}\text { Teacher preparation } \\
\text { (TP) }\end{array}$ & $\begin{array}{l}\text { - The academic content presented in the slideshow improved } \\
\text { my knowledge about the use of humour in teaching and } \\
\text { learning. } \\
\text { - I now have more self-confidence to use humour in my } \\
\text { teaching and learning. } \\
\text { - I have decided that I am not going to use humour in my } \\
\text { teaching and learning. }\end{array}$ \\
\hline $\begin{array}{l}\text { Positive factors that } \\
\text { influence teachers' } \\
\text { decisions to use humour } \\
\text { in the classroom (PF) }\end{array}$ & $\begin{array}{l}\text { - Because of the humour, I have a deeper understanding of the } \\
\text { reproductive strategies of organisms. } \\
\text { - I feel better after this class because of the humour. }\end{array}$ \\
\hline $\begin{array}{l}\text { Negative factors that } \\
\text { influence teachers' } \\
\text { decisions to use humour } \\
\text { in the classroom (NF) }\end{array}$ & $\begin{array}{l}\text { - Showing the video clip of Mr Bean in the chemistry lab to } \\
\text { learners is dangerous. } \\
\text { - Humour disrupts teaching and learning. }\end{array}$ \\
\hline
\end{tabular}

Because the lectures had formed such a vital part of the research process, it seemed necessary to describe the nature and development of one of the lectures in which the themes in Table 1 were addressed. The data analysis will be addressed in Section 7. 


\subsection{Presentation of humorous lecture}

Akin to the experiences of many educators, the first author had never intentionally used humour. Only after encountering Lovorn and Holaway's 2015 study did he realise that (his) humour could be planned, used intentionally and studied. He then also realized that he had been using humour for many years when teaching, first as a teacher and then as a lecturer. The realisation that he might in actual fact be a humorous lecturer came as a bit of an embarrassing insight to him. The encounter with Lovorn and Holaway (2015) could then be described as a cathartic one.

The sudden change in his comprehension of his use of humour had an unexpected complication: He realised that using humour was easier said than done. The first problem was to identify a relevant topic that might be presented in a humorous manner. When scrutinising the various topics to be studied by pre-service Life Sciences teachers, the reproductive strategies of flowers and animals seemed to offer some scope for humorous interpretation, especially since humans and other living organisms share many similar strategies.

A video clip of Mr Bean served to introduce the lecture. In it, Mr Bean strolls into a random chemistry laboratory and foolishly starts interfering with a seemingly complicated chemical reaction. This eventually results in a massive explosion, during which a learner seems to be hurt or even to have been killed. Since a participant in Lovorn and Holaway's study (2015: 29) specifically noted that some forms of humour could sometimes have dangerous complications, the goal was to establish whether the respondents would regard the use of a video clip of this kind to be an appropriate teaching aid.

The next section of the two presentations addressed the reproductive strategies of flowers (2018) and of humans and animals (2019). While the 2018 presentation utilised the model of a flower in the humorous description of the reproductive strategies of flowers, the reproductive strategies of animals were utilised for humorous presentation in the 2019 presentation. After referring to typical "pick-up" lines used by humans, such as "Do I know you, because you look a lot like my next boyfriend?" and "I seem to have lost my phone number. Can I have yours?", the development of the process of falling in love was illustrated. This was done by showing students the section from the Bambi movie in which Bambi's friends - the skunk and the rabbit - both fall in love in spite of seemingly being immune to it and being determined not to do so. Elements of the reproductive strategies of herons, spiders, bees, praying mantises, porcupines and bats were then "performed". The humorous discussions of flower reproduction in the lecture of 2018 and the discussion of animal reproduction in the lecture of 2019 were followed by a theoretical discussion of the themes identified by Lovorn and Holaway (2015: 27-31) - as outlined in Table 1. This second part of the presentation was done without using humour.

The survey instruments were handed out for completion immediately after each lecture in 2018 and 2019. The completion of these took more or less twenty minutes on average.

\section{Trustworthiness}

Triangulation of the knowledge produced by the data allowed us to explore the phenomenon of humour in a higher education classroom (Flick 2019: 444). The model of Lincoln and Guba (1985: 294-301) was used to establish trustworthiness by addressing four criteria. Credibility was enhanced by repeating the 2018 research in 2019 . This enabled us to sort out any potential limitations of the initial survey instrument by adding three additional items to the 2019 survey. Since the humorous topic of the first lecture had been the reproductive strategies of flowers, the rest of the survey was simply adapted to reflect the topic of animal reproduction. The purpose of repeating the research was to increase the validity of the results. This enabled us to perform a statistical comparison of the results. Dependability was enhanced by critical reflection on the 
data and by ensuring that data could be traced throughout the process. Confirmability was enhanced by being objective and staying neutral throughout the research process.

\section{Ethics approval}

When research is conducted, it is important to ensure that no harm will be done to the participants and that their rights and identities are protected (Maree 2016: 44). Ethics approval for this study was obtained from the Ethics Committee of the University of the Free State in Bloemfontein, South Africa. Care was taken that ethical considerations would be respected through the research process (Creswell \& Creswell 2018: 90). Trust and credibility were established by addressing the following issues: making sure that participants were disrupted as little as possible; respecting power imbalances; emphasising voluntary participation and confidentiality; acknowledging the right to privacy; and conducting research in a relationship of trust and transparency with the participants (Creswell \& Creswell 2018: 94). In this regard we were compelled to inform them in advance about the aims of the presentation and the research - and to get their written permission to conduct the research. A critical reader of our paper pointed to the fact that this prior knowledge of the lecture's real objectives might have affected the students' responses in the survey. We admit that this might have been the case, but we think that to present the lectures without informing the students that they formed part of a research project could be considered to be an unethical or unacceptable research practice. We recommend that such a research project should be conducted in future, but only after careful consideration of the ethical and methodological issues that arise from not informing the respondents about the objectives of the lecture.

\section{Discussion of results}

\subsection{Analysis of the teaching elements in the 2019 lecture about some reproductive strategies of animals}

Although it is not possible to use an objective instrument to "prove" that something is humorous, we viewed longer or shorter episodes of laughter subjectively as a "laughter session" when the response was clearly audible and substantial. Trivial responses were ignored. A summary of the teaching elements of the 2019 lecture is presented in Table 3 below.

Table 3 reveals that a total of 71 laughter sessions occurred during the lecture. Although it is debatable what the precise threshold number of laughter sessions per lecture should be for a lecture to qualify as humorous, it can be argued that the above qualitative data support the quantitative data, which is taken to be an indication that students interpreted the presentation as humorous (Creswell 2018: 233-234).

To enhance our presentation of the nature of the lecture, we selected one element from it to illustrate the dynamics of the presentation. The discussion was based on the picture in Figure 1, which is of a praying mantis. It might be difficult to comprehend how the reproductive strategies of an insect like a praying mantis could be humorous, but the students, for whom the lecture was developed, did indeed laugh. One should also remember that the presentation of a dynamic classroom situation on paper can never be a true reflection of the engagement between lecturer and students, and it can similarly never be a complete success. 
Table 3. Analysis of the laughter sessions during teaching elements of the lecture of 2019

\begin{tabular}{|l|c|c|}
\hline \multicolumn{1}{|c|}{ Element } & Duration in minutes & $\begin{array}{c}\text { Number of laughter } \\
\text { sessions }\end{array}$ \\
\hline Introduction & $1: 34$ & 5 \\
\hline Mr Bean video & $1: 41$ & 17 \\
\hline Bambi video clip & $4: 08$ & 32 \\
\hline Reproduction & $10: 54$ & 10 \\
\hline $\begin{array}{l}\text { Information session on } \\
\text { Lovorn and Holaway's idea } \\
\text { of humour in the classroom }\end{array}$ & $11: 40$ & \\
\hline TOTAL & & $\mathbf{7 1}$ \\
\hline
\end{tabular}

A transcription of a short section of the presentation nevertheless shows that it developed as follows:

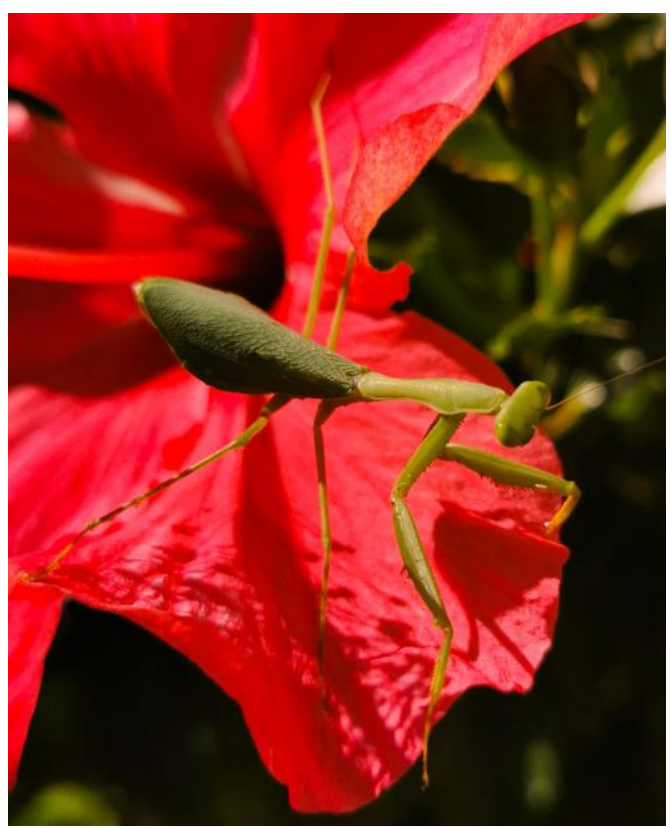

Figure 1. Picture of praying mantis projected on screen while it was discussed during the lecture of 2019. Photo by first author.

This is like a praying mantis. She eats the male on many occasions. So I can imagine a situation like that on campus ... (laughter) ... where a group of girls would be walking and a male would approach them and they would eat him and say 'Oh! How did that one taste?'; 'No, he was a bit fat.' (laughter) So it seems that the praying mantis is like praying, the male is saying: 'Please don't eat me, Sylvia, please!'... (laughter) ... and she would pray back and say, 'Please, Ronnie, I can't resist you.' (laughter) ... And then she would eat him, and in the 
mating season, sixty percent of her diet will consist of males. So it's a lot of males putting their lives at risk to ensure the survival of the species. That's why, in general terms - like, you'll know from human beings as well - men are generally useless" (laughter and a female student says "Thank you!).

The above enables us to answer our first research question in the affirmative.

\subsection{Statistical analysis of the responses}

Table 4 presents the descriptive statistics for the survey responses, for each year and theme.

Table 4. Comparison of 2018 and 2019 survey responses (descriptive statistics for average response per theme, and chi-square test comparing 2018 and 2019 responses); $5=$ Strongly agree and $1=$ Strongly disagree

\begin{tabular}{|c|c|c|c|c|c|}
\hline \multirow[t]{2}{*}{ Theme } & \multirow{2}{*}{$\begin{array}{l}\text { Descriptive } \\
\text { Statistic }\end{array}$} & \multicolumn{2}{|c|}{ Year } & \multirow{2}{*}{$\begin{array}{l}\text { Chi-square } \\
\text { statistic }^{1}\end{array}$} & \multirow[t]{2}{*}{ P-value } \\
\hline & & 2018 & 2019 & & \\
\hline \multirow[t]{3}{*}{ CEM } & $\mathrm{N}$ & 44 & 63 & & \\
\hline & Mean & 4.3 & 4.5 & 4.9011 & 0.0268 \\
\hline & STD & 0.52 & 0.58 & & \\
\hline \multirow[t]{3}{*}{ CET } & $\mathrm{N}$ & 44 & 64 & & \\
\hline & Mean & 4.3 & 4.4 & 0.7671 & 0.3811 \\
\hline & STD & 0.43 & 0.47 & & \\
\hline \multirow[t]{3}{*}{ CEI } & $\mathrm{N}$ & 44 & 63 & & \\
\hline & Mean & 4.4 & 4.5 & 0.2800 & 0.5967 \\
\hline & STD & 0.66 & 0.92 & & \\
\hline \multirow[t]{3}{*}{ TP } & $\mathrm{N}$ & 43 & 64 & & \\
\hline & Mean & 4.4 & 4.4 & 0.2907 & 0.5898 \\
\hline & STD & 0.51 & 0.62 & & \\
\hline \multirow[t]{3}{*}{ PF } & $\mathrm{N}$ & 44 & 64 & & \\
\hline & Mean & 4.4 & 4.6 & 4.3989 & 0.0360 \\
\hline & STD & 0.48 & 0.43 & & \\
\hline \multirow[t]{3}{*}{ NF } & $\mathrm{N}$ & 44 & 64 & & \\
\hline & Mean & 2.5 & 2.4 & 0.3516 & 0.5532 \\
\hline & STD & 0.83 & 0.86 & & \\
\hline \multirow[t]{3}{*}{ PRET } & $N$ & 44 & 64 & & \\
\hline & Mean & 4.3 & 4.6 & 10.5933 & 0.0011 \\
\hline & STD & 0.54 & 0.51 & & \\
\hline
\end{tabular}


Furthermore, the Mantel-Haenszel chi-square test statistic (row mean-score test) and the associated P-value comparing the mean responses for the two survey years (2018 and 2019) are shown.

From Table 4 it is clear that generally, except for NF, the mean responses were high, with all the means falling within the range of 4.3 to 4.6 across the two years. In contrast, for NF, the mean responses for 2018 were 2.5 and 2.4 for 2019 . When one considers the negative nature of the four items in the surveys that were measuring negative factors that might influence teachers' decisions to use humour in the classroom (see Table 3), it seems clear that this was only to be expected. The responses do, however, indicate that the respondents were cautious about the possible negative consequences of using humour in the classroom, since the means in both cases seem to approach notable levels of uncertainty. One could generalise by stating that the respondents did indeed disagree with, for example, the statement that humour disrupts teaching and learning, but not very strongly: they were almost uncertain. Lovorn and Holway's concerns (2015: 30-2) regarding the use of humour thus seem to be validated.

Furthermore, with the exception of CEM and PRET, the mean responses for the two years were quite similar for most themes that exhibited no statistically significant differences between the two years. In contrast, for CEM $(\mathrm{P}=0.0268)$ and PRET $(\mathrm{P}=0.0011)$, the mean responses were statistically significantly higher in 2019 as compared to 2018 . Thus, in each case, there was an increase in mean response from 2018 to 2019, but in practical terms, these increases (CEM: from 4.3 to 4.5 and PRET: from 4.3 to 4.6 ) can be considered slight. In practical terms, one might conclude - or so the first author would like to believe - that the 2019 presentation was slightly more humorous than that of 2018 , since the first writer had become a bit more confident in his humoristic abilities. The second lecture was also planned better. Overall, however, the survey responses for 2018 and 2019 can be said to be quite similar.

\subsection{Supportive role of the qualitative data}

According to Creswell (2019: 196), predetermined codes can be used, and the data can then be fit to them. Content analysis was used to achieve a fit between the qualitative data and the predetermined codes (Table 2). In exploring the supportive role of the qualitative data, it seemed necessary to describe and analyse teaching elements of the humorous lecture.

Content analysis was used to elicit students' ideas on the phenomenon of humour in the classroom (Allen 2017: 1). This was done in accordance with the predetermined themes in tables 2 and 3. While humour in a lecture hall has pedagogical value, it does not always come naturally. In fact, according to Wanzer et al. (2010: 1-5), it is not a given that students will find the lecturer's presentation humorous. Bearing these reservations in mind, the first author intentionally planned how humour could be implemented in the lectures. Care was taken to select relevant learning material that students may find humorous in order to have the desired effect of engaged learning. While the presenting lecturer does not see himself as a stand-up comedian, this study was prompted to investigate the use of content that may elicit a positive effect in students. In Section 1, it is emphasised that the perception about the intended humour will determine whether attention is sustained (Deiter 2000: 22). Students must first cognitively appraise something as funny; otherwise, the positive emotion of amusement will not be created (Wanzer et al. 2010: 3). The results in tables 3 and 4 suggest that most of the students found the teaching elements and content of the lectures humorous. Qualitative responses supported this conclusion:

It was hilarious, especially when he tried to get rid of the smoke using his hand.

It was very funny and made all the students laugh.

It was hilarious but informative. 
A closer look at students' comments demonstrates that although they perceived the presentations as humorous, the humour did not compromise content but rather created a relaxed atmosphere when dealing with a difficult topic:

Even though he made jokes, he effectively explained the reproductive strategies for better understanding of the learner.

It is not a comfortable topic but using humour makes it easy to present to the learners.

Humour removes the awkwardness of a topic and makes it funny.

Humour should be used. This topic is rather awkward on its own. It becomes better with humour in it.

The above views confirm that students do not expect laughter to be a substitute for learning. When choosing a theme, such as the reproductive system, the humour should not affect students negatively, it should not create situations that they may find awkward or lead to disruptive behaviour.

But one must be careful for the jokes used.

I am not sure if humour should be used in all aspects of reproduction.

Sometimes learners can get disruptive while laughing.

Humour can be used, but [only] when used correctly.

People with a good sense of humour will find it amazing and others might not.

Sometimes the learners can laugh non-stop and decide to continue talking.

It depends on the type of humour and the discipline within the class.

Bolkan et al. (2018: 164) concur by claiming that, although humour can create a relaxed atmosphere, the lecturer should be careful not to use humour in presentations in such a way that it will compete for the students' attention. The lecturer should not attempt to be a clown, remembering that students still expect subject expertise where the main focus is student learning (Deiter 2000). Classroom management is still an integral part of effective teaching. Classroom management, therefore, also implies keeping students focused and engaged in the learning process. Gonulat (2018: 156) indeed reports that the excessive use of humour in classrooms does more harm than good, probably because there is a saturation point for humour.

Student interaction and engagement in learning are complex concepts to define and can be said to be an umbrella term that integrates a number of aspects. Cauley and McMillan (2010: 6) interpret classroom interaction as an opportunity for students to be actively involved in educational experiences in order to master autonomy and develop self-efficacy. According to Pears (2010: 1,2), positive factors, for example students' beliefs and perceptions, will influence their motivation to learn.

From the above discussion, it follows that appropriate, humour-related course content can create a positive classroom environment, which, in turn, influences feelings and motivation. The positive affect generates curiosity that can act as a teaching tool to facilitate learning. Positive affect that captures students' attention may increase their ability and motivation to interact cognitively and socially (Bolkan et al. 2018: 146). Establishing a relaxed classroom environment requires the involvement of both reasoning and emotions (Chabeli 2008: 54). These two components cannot be separated because learning involves both rational and affective endeavours (Chabeli2008: 54). In this regard, Gonulal (2018: 155) points to the fact that participants in his study found teachers with a sense of humour both more approachable and 
likeable.

The results in tables 3 and 4 would lead us to believe that humour in this classroom created a comfortable and relaxed atmosphere. This was borne out by the participants' qualitative responses:

I have learned that in the classroom you do not have to be very serious every time. Using humour can make the classroom very enjoyable to learners.

I have learned that humour can actually be a stress reliever. So, I will use it.

I came with stress to class but now I feel relaxed.

I felt relaxed in the class where I usually feel stressed between a lot of people.

Humour eases tension in class and help[s] learners to learn effectively.

The humorous way eases the tension for students to feel comfortable enough to ask/listen. It breaks the thought and doctrine of not talking about such [things] with elders that we get from home.

The appropriate use of humour has the power to transmit energy to the students and create a relaxed atmosphere (Jeder 2015: 829). In a relaxed and safe environment, students feel happy. They feel free to investigate, ask critical questions, make mistakes and attempt to solve problems (Chabeli 2008: 16). When students are smiling, they will be more motivated to engage in learning. In agreement with IHPT, the following student pointed out that the positive affect created by the humorous presentation motivated him/her to focus on the content of the lecture:

I listened to every word because I did not want to miss out on anything.

It appears that when students share laughter, this will create a relaxed atmosphere. By creating social connections, humour may lower defences and encourage challenging interactions (Chabeli 2008: 54), the focus here being on the social engagement:

People who laugh at the same things, can connect to the same things.

The humour worked well with the topic as everyone could relate to the topic and also the humour makes [for] a good after class discussion amongst students.

The above comments particularly highlight that dialogue will be stimulated and provide opportunities for students to interact and participate in learning (Chabeli 2008: 54; Gonulal 2018: 156). When the lecturer creates a positive emotional and social connection, humour may lower barricades, and students will be able to focus better and create opportunities for cognitive interaction (Chabeli 2008: 54). This idea concurs with Munoz's opinion (2005: 24) that humour is closely related to memory because it will be easier for students to recall facts presented in a humorous way. Students tended to agree:

Yes I will remember everything easier and easier recall information.

Yes, it makes it easier to remember and will stay in my brain for a long period.

... it was very interesting because it explained new information in a funny way, which will possibly help me in remembering the information.

It kept my concentration better in the sense that I only concentrated during parts where facts were presented and relaxed otherwise. This ensures that the important information gets remembered. 
The humour made things that I can relate to funny and it is easier to remember something funny that relates to you.

Bolkan et al. (2018: 146) maintain that by incorporating humour into one's teaching, students' information-processing skills can be enhanced. Taking ownership or making sense of content is vital for successful learning. The following comment by a student signals agreement with this point of view:

It encouraged me to try using humour in my lessons.

According to Chabeli (2008: 54), "[a] positive use of humour can challenge learners to engage in problem- solving activities, the resolution of contradictions, and the justification of their views."

The preceding discussion bears out the opinion of Lovorn and Holaway (2015), namely that the appropriate use of humour has the power to transmit positive energy to the students and create a relaxed atmosphere. In a relaxed and safe environment, students are bound to feel happy (Jeder 2015: 829), they feel free to investigate, ask critical questions, make mistakes and attempt to solve problems (Chabeli 2008: 16). When students are smiling, they will be more motivated to engage in learning.

\section{Limitations}

Although one could use a sequential mixed-methods design with a more extensive qualitative data-collection method, in our case, time constraints made that a less attractive option. We have also pointed to the possibility that the students' prior knowledge of the objectives of the research and lecture might have affected their responses. We have recommended that further research is needed to address this limitation.

\section{Conclusion}

When considering our first research question, namely whether an intentional, planned, humorous lecture would be perceived as such by student respondents, we are confident that we could, in both qualitative and statistical terms, conclude that this was the case and that the respondents did indeed perceive the lecture as humorous. In regard to the second research question, namely whether the six themes identified and discussed by Lovorn and Holaway (2015) would be perceived as useful and applicable by the student respondents, we similarly have concluded that it seems reasonable to accept that all of the six themes have generally been perceived to be both useful and applicable. As such, the content taken from the study of Lovorn and Holaway (2015) that was presented to the respondents has been validated as being largely appropriate, useful and applicable in both tertiary and K-12 teaching and learning environments.

The words of Garner (2006: 180) summarise the message of this study: "When properly used, humour can be an effective tool to make a class more enjoyable, reduce anxiety and improve the learning setting. The 'ha-ha' of humour in the classroom may indeed contribute to the 'aha' of learning from the student."

\section{Acknowledgement}

We sincerely thank Professor Petra Engelbrecht, who acted as a critical reader of this paper. 


\section{References}

Alatalo, S. \& Poutiainen, A. (2016). 'Use of humor in multicultural classroom'. The Israeli Journal of Humor Research 5 (1), pp. 65-79.

Allen, M. (2017). 'Content analysis'. Available online: https://dx.doi.org/10.4135/9781483381411.n91 [Accessed on 28 June 2019].

Alkhattab, M. A. (2012). Humor as a Teaching Strategy: The Effect on Students' Educational Retention and Attention in a Nursing Baccalaureate Classroom. Indiana: College of Nursing of Valparaiso University MA thesis.

Azizinezhad, M. \& Hashemi, M. (2011). 'Humour: a pedagogical tool for language learners'. Procedia: Social and Behavioural Sciences. Available online: www.sciendedirect.com. [Accessed on 20 October 2018].

Bakar, F. A. B. (2018). The Use of Humour in Teaching and Learning in Higher Education. Dunedin, New Zealand: University of Otago PhD thesis.

Banas, J. A., Dunbar, N., Rodriquez, D. \& Liu, S.J. (2011). 'A review of humor in educational settings: four decades of research'. Communication Education 60 (1), pp. 115-144.

Baughman, M. D. (1979). 'Teaching with humour: a performing art'. Contemporary Education 51, pp. 26-30.

Berk, R. A. (2002). Humor as an Instructional Defibrillator: Evidence-based Techniques in Teaching and Assessment. Virginia: Stylus.

Berlyne, D. E. (1960). Conflict, Arousal and Curiosity. New York: McGraw-Hill.

Bian, H. (2016). 'Mixed method research'. PowerPoint presentation. Available online: https://core.ecu.edu/ofe/statisticsresearch/mixed\%20methods\%20new.pdf [Accessed on 13 August 2019].

Bolkan, S. \& Goodboy, A. K. (2015). 'Exploratory theoretical tests of the instructor humorstudent learning link'. Communication Education 64 (1), pp. 45-64.

Bolkan, S., Griffin, D. J. \& Goodboy, A. K. (2018). 'Humor in the classroom: the effects of integrated humor on student learning'. Communication Education 67 (2), pp. 140-164.

Booth-Butterfield, S. \& Booth-Butterfield, M. (1991). 'Individual differences in the communication of humorous messages'. Southern Communication Journal 56 (2), pp. 05218.

Budzynska, K. \& Weger, H. (2011). 'Structure of persuasive communication and elaboration likelihood model'. OSSA Conference Archive, 67. Available online: http://scholar.uwindsor.ca/ossaarchive/OSSA9/papersandcommentaries/67 [Accessed on 22 October 2018.

Cauley, K. \& McMillan, J. H. (2010). 'Formative assessment techniques to support student motivation and achievement.' The Clearing House 83 (1), 1-6.

Cohen, L., Manion, L. \& Morrison, K. (2011). Research Methods in Education, $7^{\text {th }}$ ed. Oxford: Routledge.

Creswell, J. W. \& Creswell, J. D. (2018). Research Design, Qualitative, Quantitative \& Mixed Methods Approaches. Los Angeles: Sage.

Davenport, D. C. (2015). Examining Peer Perceptions of Humorous Communication in the College Classroom. Theses and Dissertations-Communication 42. Available online: https://uknowledge.uky.edu/comm-etds/42. [Accessed on 25 October 2018].

Deiter, R. (2000). 'The use of humor as a teaching tool in the college classroom'. NACTA Journal 44, pp. 20-28.

Feilzer, Y. (2009). 'Doing mixed methods research pragmatically: implications for the rediscovery of pragmatism as a research paradigm'. Journal of Mixed Methods Research 4 (1). Available online: Doi:10.1177/155868980349691 http://jmmr.sagepub.com [Accessed on 2 January 2019]. 
Flick, U. (2017. 'Triangulation', in Denzin, N. K. \& Lincoln, Y. L. (eds.), The SAGE Handbook of Qualitative Research, London: Sage, pp. 444-462.

Freitas, T. M. (2018). Student Perceptions of Instructor Humor as a Predictor of Student Intellectual Stimulation, Academic Interest and Engagement. Theses and DissertationsUniversity of the Pacific, Thesis. Available online: https://scholarlycommons.pacific.edu/uop-etds/3117 [Accessed on 24 October 2018].

Garner, R.L. (2006). 'Humor in pedagogy: How ha-ha can lead to aha!'. College Teaching 54 (1), pp. 177-180.

Gervais, M. \& Wilson, D. S. (2005). 'The evolution and functions of laughter and humor: a synthetic approach'. Quarterly Review of Biology 80, pp. 395-430.

Gonulal, T. (2018). 'Investigating the potential of humour in EFL classrooms: an attitudinal study'. The European Journal of Humour Research 6 (1), pp. 141-161.

Healy, B. (2018). 'What makes something funny?' The Atlantic. Available online: https://www.theatlantic.com/magazine/archive/2018/03/funny-how/550910/. [Accessed on 3 July 2019].

Huss, J. \& Eastep S. (2016). 'The attitudes of university faculty toward humor as a pedagogical tool: can we take a joke?'. Journal of Inquiry \& Action in Education 8(1), pp. 39-65.

Jeder, D. (2015). 'Implications of using humor in the classroom'. Procedia: Social and Behavioral Sciences 180, pp. 828-833.

Johnson, B. R. \& Christensen, L. B. (2017). Educational Research: Quantitative, Qualitative and Mixed Approaches. Los Angeles: Sage.

Kroll, T. \& Neri. M. (2009). 'Designs for mixed methods research'. In Andrew, S. \& Halcomb, E. J. (eds.), Mixed methods research for nursing and the Health Sciences, Hoboken: Wiley-Blackwell.

Lei, S. A., Cohen, J. L. \& Russler, K. M. (2010). 'Humor on learning in the college classroom: evaluating benefits and drawbacks from instructors' perspectives'. Journal of Instructional Psychology 37, pp. 326-331.

Lincoln, Y. S. \& Guba, E. G. (1985). Naturalistic Inquiry. London: Sage.

Loomans, D. \& Kolberg, K. J. (1993). The Laughing Classroom: Everyone's Guide to Teaching with Humor and Play. Tiburon: H. J. Kramer.

Lovorn, M. \& Holaway, C. (2015). 'Teachers' perceptions of humour as a classroom teaching, interaction and management tool'. The European Journal of Humour Research 3 (4), pp. 24-35.

Machlev, M. (2015). A Day without Laughter is a Day Wasted. The Relationship between Different Types of Humour and Different Educational Outcomes. Dissertations. Paper 37. Available online: http://digscholarhipunco.edu/dissertations. [Accessed on 24 October 2018].

Malamed, C. (2018). 'Does humor enhance learning? E learning couch'. Available online: https://elearning design/instructional design. [Accessed on 23 October 2018].

Maree, K. \& Pietersen, J. (2016). 'Sampling', in Maree, K. (ed.). First Steps in Research, Pretoria: Van Schaik, pp. 192-202.

Mayo, C. (2010). 'Incongruity and provisional safety: thinking through humor'. Studies in Philosophy and Education 29, pp. 509-521.

Morreall, J. (2014). 'Humor, philosophy and education'. Educational Philosophy and Theory 46 (2), pp. 120-131.

Morreall, J. (2016). 'Philosophy of Humor'. The Stanford Encyclopaedia of Philosophy. Available online: https://plato.stanford.edu/archives/win2016/entries/humor [Accessed on 2 March 2020].

Morrison, M. K. (2008). Using Humour to Maximize Learning: The Links between Positive Emotions and Education. Lanham, MD: Rowman \& Littlefied. 
$\mathrm{Mr}$ Bean in the chemistry lab. Available online: https://www.youtube.com/watch?v=6aK2CKrdjbE [Accessed on 21 April 2019].

Munoz, B. J. (2005). 'Learning through humor: using humorous resources in the teaching of foreign languages'. The A.T.I.S Bulletin, pp. 42-46.

Ocon, R. (2015). 'Using humour to create a positive learning environment'. Proceedings of the ASEE Annual Conference \& Exposition, pp. 1-26.

Offer, K., Skead, N. \& Seen, A. (2018). 'You must be joking: the role of humour in the law classroom'. The Law Teacher 52 (2), pp. 135-153.

Pears, A. N. (2010). 'Enhancing student engagement in an introductory programming course'. ASEE/IEE Frontiers in Education Conference, 27-30 October 2010, Arlington. Available online: http://www/fie-conference.org/fie2010/papers/1195.pdf [Accessed on 10 August 2010].

Perks, L. G. (2012). 'The ancient roots of humor theory'. Humor 25(2), pp. 119-132.

Petty, R. E. \& Cacioppo, J. T. (1986). 'The elaboration likelihood model of persuasion'. Advances in Experimental Psychology 19, pp. 123-205.

SAS Institute Incorporation. (2017). SAS/STAT 14.3 User's Guide. Cary, NC: SAS Institute Inc.

Savage, B. M., Lujan, H. L., Thipparthi, R. R. \& DiCarlo, S. E. (2017). 'Humor, laughter, learning and health! A brief review'. Advances in Physiology Education 41, pp. 341-447.

Seidman, A., \& Brown, C. (2016). 'Laugh and learn'. Adult Learning 27 (1), pp. 41-43.

Strong, T. (2013). 'The culture of humour in the classroom: the good, the bad and the other. Canadian Music Educator pp. 31-33.

$\mathrm{Vu}, \mathrm{P}$. H. \& Vu, L. (2012). 'Techniques to bring humor and crate a pleasant learning environment in Adult Education'. Journal of Research and Practice for Adult Literacy, Secondary and Basic Education 1 (1), pp. 44-47.

Wagner, C., Kawulich, B. \& Garner, M. (2012). Doing Social Research: A Global Context. Berkshire: McGraw-Hill Education.

Wanzer, M. B., Frymier, A. B. \& Irwin, J. (2010). 'An explanation of the relationship between instructor humor and student learning: instructional humor processing theory'. Communication Education 59 (1), pp. 1-18.

Wium, A. M. \& Louw, B. (2018). Mixed-methods research: a tutorial for speech-language therapists and audiologists in South Africa'. South African Journal of Communication Disorders 65 (1), pp. 1-13.

Wortley, A. (2016). 'Stand-up comics: instructional humor and student engagement. Grand Canyon University'. Journal of Instructional Research 5, pp. 13-18. 